\title{
PATHOMORPHOLOGICAL CHARACTERISTICS OF ABOMASAL ULCERS IN HIGH-YIELDING DAIRY COWS
}

KURELJUŠIĆ B*, IVETIĆ V*, SAVIĆ B*, JEZDIMIROVIĆ N*, CVETOJEVIĆ Đ*, KURELJUŠIĆ JASNA*, ILIĆ ŽIVKA*, STANOJEVIĆ S* and STEVANČEVIĆ M**

\footnotetext{
*Institute of Veterinary Medicine of Serbia, Belgrade

**University of Novi Sad, Faculty of Agriculture, Veterinary Department, Novi Sad, Srbija
}

\author{
(Received $1^{\text {st }}$ November 2012)
}

The aim of this paper was to investigate the morphology, localization and typization of abomasal ulcers in high-yielding dairy cows, as a contribution to the existing knowledge on the subject.

A total of ten high-yielding dairy cows which died during the period of early puerperium and two Holstein heifers which died in late pregnancy after transport to a new location were investigated in this study. Samples of altered abomasal tissue were taken at necropsy for further histopathology and mycology investigations.

The disclosed ulcerations of the abomasums in twelve investigated animals differed among them not only as far as localization and morphology are concerned, but also in the degree of intramural penetration. Such differences distinguished them into four types. Ulcerations of type one and type two, recorded in two heifers and six cows, as well as in one cow with lymphoma of the abomasum. Perforating ulcer of type three, with circumscripted peritonitis was diagnosed in one cow in the corpus of the abomasum close to the curvatura major. An interesting finding was the simultaneous occurrence of type four perforating ulcer and ulcer-type one, which were located next to each other.

Histopathological examination of the structure of the ulcerated abomasum dyed with the hematoxylin-eosin method showed that coagulation necrosis in the area of the ulceration revealed a moderate inflammatory infiltrate in the lamina propria. In the cow affected with lymphoma, a copious tumorous lymphoid infiltrate was concurrent.

Mycotic ulcerative abomasitis was described in a cow seven days after calving. In these lesions Aspergillus fumigatus and Mucor spp. were isolated. Histopathological analysis of tissue samples dyed with the Grocott method, described septed and nonsepted hyphae in the blood vessels and surrounding tissue of the tunica mucosa and submucosa.

Key words: abomasum, cow, pathomorphology, ulcus 


\section{INTRODUCTION}

Abomasal ulcers are a local process of autodigestion of the mucosa. It develops under the influence of acid peptic activity, or it is the result of pathophysiological conditions under which it cannot oppose the destructive action of the gastric juice, as the balance between protective and destructive processess is altered. Abomasal ulcers are a significant cause of indigestions in dairy cows. They can develop not only in cows, but in calves and in beef cattle, also (Ostertag, 1989; Marshall, 2009; Tharwat and Ahmed, 2012).

The etiology of abomasal ulcers is still unclear, and the effect of polyvalent stress often referred to as the principal cause. With this in mind the puerperal period is of upmost significance as it a very stressful period for high-yielding dairy cows. In addition, transport, diet, mastitis, liver and lung diseases, some infectious diseases, as well as abomasal dislocations can be predisposing factors (Braun et al., 1991; Cable et al., 1998; Brown et al., 2007; Marshall, 2009). Dirksen (1989) reported that $50 \%$ of deep, penetrating ulcers are linked to left-side dislocations of the abomasum. Interestingly, Zauscher (2007) accounted ulcers type 3 to be connected to left-side dislocations of the abomasum.

Acid indigestion which develops as the result of inadequate diet can also contribute to the development of ulcers (Šamanc, 2009). A new potentially ulcerogenic agent „Candidatus Helicobacter bovis” has been discovered in cattle. It is so called due to the fact that its taxonomic classification has not been yet carried out, despite the fact that it was confirmed by immunohistochemical, biochemical and electron microscopy procedures. However, its role in the development of ulcers in cows has not been described yet (De Groote et al., 1999).

Disturbed microcirculation in the mucosa and submucosa are often mentioned as factors in the development of ulcers. However, there are no adequate studies which would prove that there is a relative ischemia on the loci which are predisposed for the development of ulcers (Šamanc, 2009).

Besides, cases of abomasal ulcers in cows with lymphoma of the abomasum (Palmer and Whitlock, 1983), as well as mycotic ulcerative abomasitis in cows with poor immune response as a result of infection with vasoactive fungi were described (Brown et al., 2007). Peptic ulcers of the abomasum should be distinguished from secondary ulcers which accompany rinderpest, malignant catharral fever, mucosal disease, actinomycosis and tuberculosis (Brown et al., 2007).

In high yielding dairy cows contrary to duodenal ulcers, the ulcers present in the abomasum are a common finding and often have a tendency to progress. In a study carried out by Johansen et al. (1989) abomasal ulcers were documented in $57 \%$ slaughtered cattle which previously did not display any clinical symptoms. In another study abomasal ulcers were recorded in $20.5 \%$ slaughtered cows (Braun et al., 1991). Tehrani et al. (2012) described erosions and ulcers as the most common changes in slaughtered cattle. These changes can be found in different parts of the abomasum, but in dairy cows they are most often found in the corpus (Zauscher, 2007). Dirksen (1989) and Zauscher (2007) are of the opinion that the 
predilective site for perforations is on the large curvature of the abomasum. According to their opinion the most favorable outcome is that the spilled content triggers the development of an abscess on the site of the omentum adhesion. However, what often happens is that perforations result in bursitis of the omentum and circumscriptive or diffuse peritonitis. Abomasal ulcers are mainly multiple and rarely develop as solitary. They are clearly demarked from the surrounding mucosa, and often burdened with necrotic debris and blood clots. Their radius ranges from a few millimeters up to five centimeters, and can be round, oval or polymorph in shape (Marshall, 2009). The radius of the perforation sometimes has a decisive role for the developing ulcus type. According to studies by Zauscher (2007) a radius of 1 to $3 \mathrm{~mm}$ on the perforation site results in type 3 ulcers; perforations from 1.25 to $3 \mathrm{~cm}$ result in type 4 ulcerations. In acute ulcers the lumen of the abomasum is burdened with a larger quantity of clotted blood which can be mixed with its contents (Šamanc, 2009; Rademacher and Lorch, 1999). This often happens when the left and right branch of the artery and vena gastroepiploica are damaged (Zauscher, 2007). Sometimes defects or perforations of the spiral abomasal plicae can develop, also. According to Whitlock (1980) depending on the degree of penetration into the abomasal wall four ulcer types can develop: type 1 represented by shallow defects which reach deeper than the lamina muscularis of the mucosa, but with no hemorrhage; type 2 is a hemorrhaging deeper defect of the wall of the abomasum; type 3 are perforating ulcers with localized peritonitis, and type 4 are perforating ulcers with ongoing acute diffuse peritonitis (Whitlock, 1980). Type 1 ulcers mainly exibit an inapparent course and usually are diagnosed at slaughter (Whitlock, 1980). Some authors type 1 ulcers classify into four sub-types: sub-type 1a has minimal defects of the mucosa; sub-type $1 \mathrm{~b}$ is defined by deeper defects with local bleeding; subtype 1c are ulcers shaped as craters; ulcers of subtype 1d have two forms: ulcers whose crests converge towards the center of the ulceration and ulcers with perforations of the spiral abomasal plicae (Braun et al., 1991).

The aim of this paper was to examine the morphology, localization and typization of abomasal ulcers in high-yielding dairy cows, as a contribution to the existing knowledge on ulcerogenesis.

\section{MATERIAL AND METHODS}

\section{Gross examination}

In this study a total of ten high-yielding cows which died in early puerperium and two gravid Holstein breed heifers previously imported and deceased 10 days after transport were included. On necropsy samples of altered abomasal tissue were taken for histopathological and mycological survey. Depending on the degree of penetration into the abomasal wall ulcers were classified into four types according to Whitlock (1980). 


\section{Histopathology}

Samples for histopathology were fixed in $10 \%$ buffered formalin, processed by standard protocol and cast into paraffin blocks. Paraffin $5 \mu \mathrm{m}$ thin slices were dyed with hematoxylin-eosin (HE) and Grocott method.

\section{Mycological examination}

Samples of the abomasum taken for mycological examination were inoculated on Sabouraud dextrose agar and incubated at $25^{\circ} \mathrm{C}$ in aerobic conditions in order to isolate the infective agent. To avoid bacterial contamination to the substrate were added $20 \mathrm{IU} / \mathrm{mL}$ penicillin $\mathrm{G}$ and $40 \mathrm{mg} / \mathrm{mL}$ streptomycin sulfate. Macroscopic and microscopic examinations of the formed colonies were carried out according to Quinn (2002).

\section{RESULTS AND DISCUSSION}

The disclosed abomasal ulcers in twelve necropsied animals differed between them in localization, morphology, and degree of penetration. In two heifers and six cows type 1 and 2 ulcers were disclosed. These ulcers were multiple and localized in the corpus and pylorus, one close to the other and mainly round, oval or irregular in shape. They penetrated down to the submucosa, or deeper in the muscular layer (Figure 1a). The margins were mainly smooth, and the bottom in the majority of them was hemorrhagic. Over such lesions purulent bacteria can penetrate with subsequent local purulent inflammation. It is certain that at the stage of healing stenosis of the pylorus can develop. According to ulcer sub-typization (Braun et al., 1991) in one cow with type 1 ulcers the sub-type 1d was diagnosed. This sub-type is characterized by partial and total perforations of the plicae spiralis (Figure 1b). Sub-type 1d ulcer was diagnosed in a cow suffering from type 2 ulcer as ulcerations of the plica spiralis (Figure 1c). What are the true pathophysiological mechanisms of these lesions we still have no explanation.

According to the extent of bleeding we have classified type 2 ulcers into two sub-types: $2 a$ characterized by intraulceral hemorrhage and $2 b$ with profuse, even fatal, intraluminal gastric bleeding (Figure 1d, Figure 1e, Figure 1f). Bleeding is the result of erosions of large blood vessels (Rademacher et Lorch, 1999; Lorch et Rademacher, 2004; Šamanc, 2009).

It can be supposed that the transport of heifers was the cause of multiple ulcerations, as it is a fact that long transport can be considered as a stress factor (Brown et al., 2007). Besides, heifers were diagnosed with bronchopneumonia, which could have in turn, contributed to the development of ulcers as hypoxia decreases the resistance of the gastric mucosa and hypercapnia increases the secretion of hydrochloric acid (Burijan, 1980). Bearing in mind that the cows with the described ulcerations were in early puerperium, it is possible that in this case stress was the predisposing factor. It is known that stress induces splanchnic vasoconstriction with reduced perfusion of the mucosa, thus causing its lesions by inhibiting the secretion of the protective mucilaginous layer or the secretion of cytoprotective prostaglandins. Surely, at this point glucocorticosteroids which inhibit the regenerative ability of the gastric epithelium and secretion of 
Acta Veterinaria (Beograd), Vol. 63, No. 2-3, 237-246, 2013.

Kureljušić B et al.: Pathomorphological characteristics

of abomasal ulcers in high-yielding dairy cows

prostaglandin $\mathrm{E}$ and bicarbonates should not be neglected. In such a case regressive changes of the mucosa can develop quickly, and if stress lasts for a longer period the chance for the penetration of pepsin and hydrochloric acid into the lesions increases (Šamanc, 2009; Marshall, 2009).
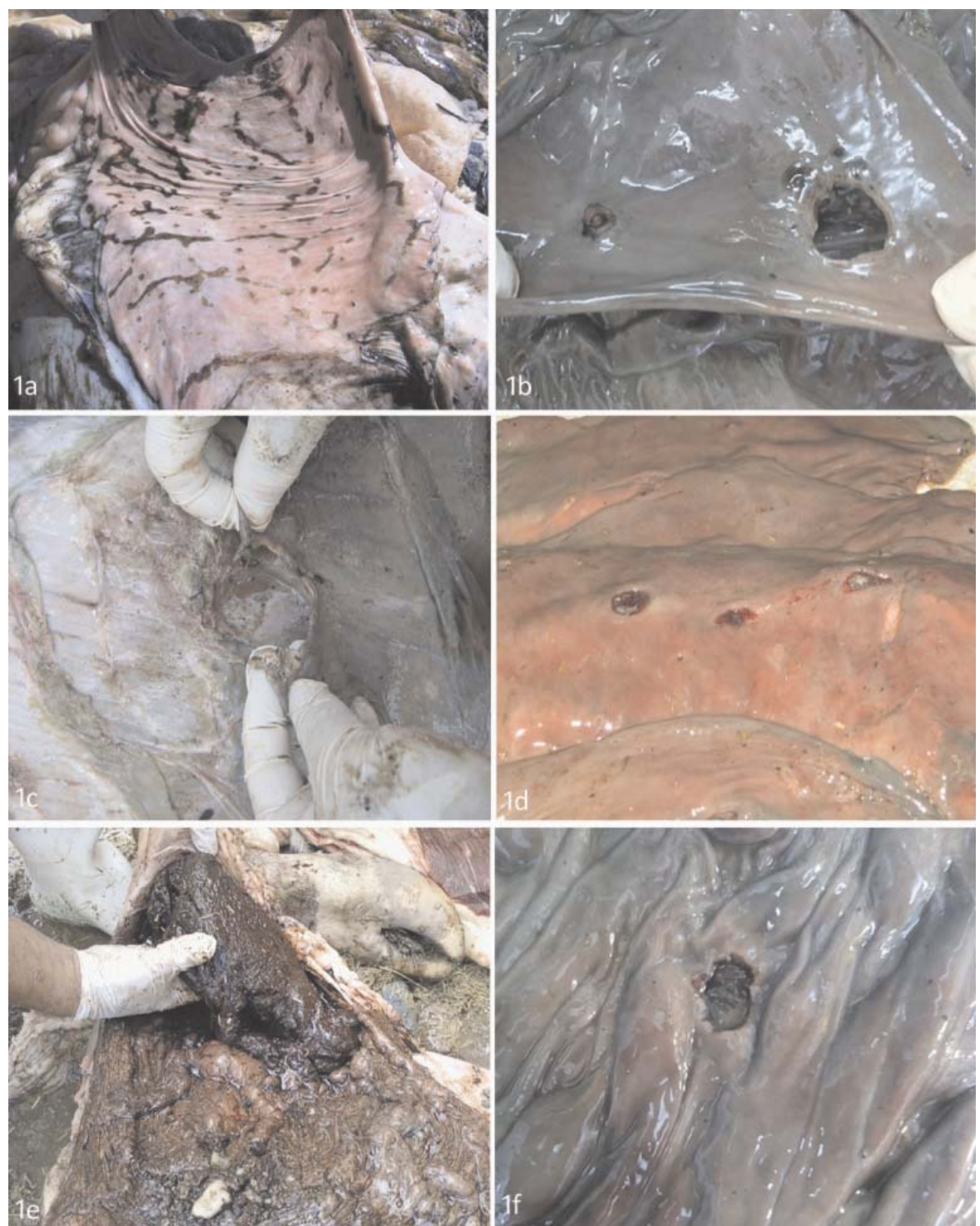

Figure 1. Cow abomasum; $1 \mathrm{a}$ - ulcerations type 1 and 2 on the pylorus; $1 \mathrm{~b}$ - perforation of the plica spiralis; $1 \mathrm{c}$ - ulceration of the margin of the plica sprialis, $1 \mathrm{~d}$ - ulcer sub-type $2 a$ with intraulceral bleeding; $1 \mathrm{e}$ - ulcer sub-type $2 \mathrm{~b}$ with blood clot, $1 \mathrm{f}$ - ulcer subtype $1 \mathrm{~b}$ from the previous picture after removal of the clot 
Type 1 and type 2 ulcerations were observed in one cow suffering from lymphoma which was characterized by a thickening of the wall of the abomasum and its spiral plicae. Ulcerations were multiple and mainly oval in shape, located one after the other in the corpus and pylorus of the abomasum (Figure 2a). Literature data report cases of abomasal ulcers in cows with lymphoma of the abomasum (Palmer et Whitlock, 1983) which most probably developed as the result of increased pressure by the tumorous proliferate on the blood vessel wall, thus compromising blood microcirculation. These ulcerations can be classified as secondary ulcers as they are the result of an undermining primary disease.

Perforating type 3 ulcer with concurrent circumscriptive peritonitis was diagnosed in one cow (Figure 2b). The ulceration was $3 \mathrm{~mm}$ in radius, and was located in the corpus closer to the curvatura major. This was the case of a small total perforation on the abomasal wall, hence no extensive spilling of the gastric content into the peritoneal cavity was possible. On the site there was a previous exudation of fibrin and adhesion of the serosa when local peritonitis occurred with possible subsequent coverage of the perforation. Fibrin organization resulted in the fusion of two corresponding serosa. The radius of the perforation was $3 \mathrm{~mm}$, which in the opinion of Zauscher (2007) causes type 3 ulcers. Simultaneously, in the abomasal content of this cow a geosediment consisting of sand and gravel was found (Figure 2c). It is well known that foreign bodies in the abomasum can cause irritation and minor erosions, thus predisposing the tissue to ulcerogenesis (Šamanc, 2009; Marshall, 2009).

As interesting, results the finding of concurrent perforating type 4 ulcer characterized by gastric spillage into the peritoneal cavity and type 1 ulcer in the corpus of the abomasum in one cow in early puerperium. Located one close to the other, they give the impression that they are confluent with a defect radius $7 \times 4 \mathrm{~cm}$ (Figure 2d). The perforating ulcus has the shape of a funnel with a $1.5 \mathrm{~cm}$ opening, which matches Zauscher (2007) criteria for type 4 ulcers with concurrent peritonitis (Figure 2e). The opening on the serosa is smaller than the defect on the mucosa, probably due to difficult peptic digestion of the serosa or stronger retraction of the mucosa. For the development of peritonitis swift digestion of the serosa was responsible when no time was left for its adhesion to neighboring organs. It is important to note that in the lumen of the abomasum there was no blood present, which indicates a chronic process, which among other things is characterized by narrowing and thrombosis of the lumen of blood vessels. It is known that perforated ulcers can lead to localized bursitis of the omentum, or diffuse peritonitis, and subsequent septic shock (Palmer and Whitlock, 1984; Šamanc, 2009). Simultaneously in this cow fatty metamorphosis of the liver was disclosed. Such hepatic pathology can inhibit the inactivation of histamine in the liver, with consequent hyperchlorhydria. Such ulcerogenesis was described in human patients with liver cirrhosis (Burijan, 1980).

Histopathological testing of the samples taken from the ulcerated abomasum, and dyed with hematoxillin-eosin coagulation necrosis and moderate inflammatory infiltrate in the lamina propria were found (Figure 2f). In the cow with lymphoma, besides this a copious tumorous lymphoid infiltrate was described, as well. 
Acta Veterinaria (Beograd), Vol. 63, No. 2-3, 237-246, 2013.

Kureljušić B et al.: Pathomorphological characteristics

of abomasal ulcers in high-yielding dairy cows
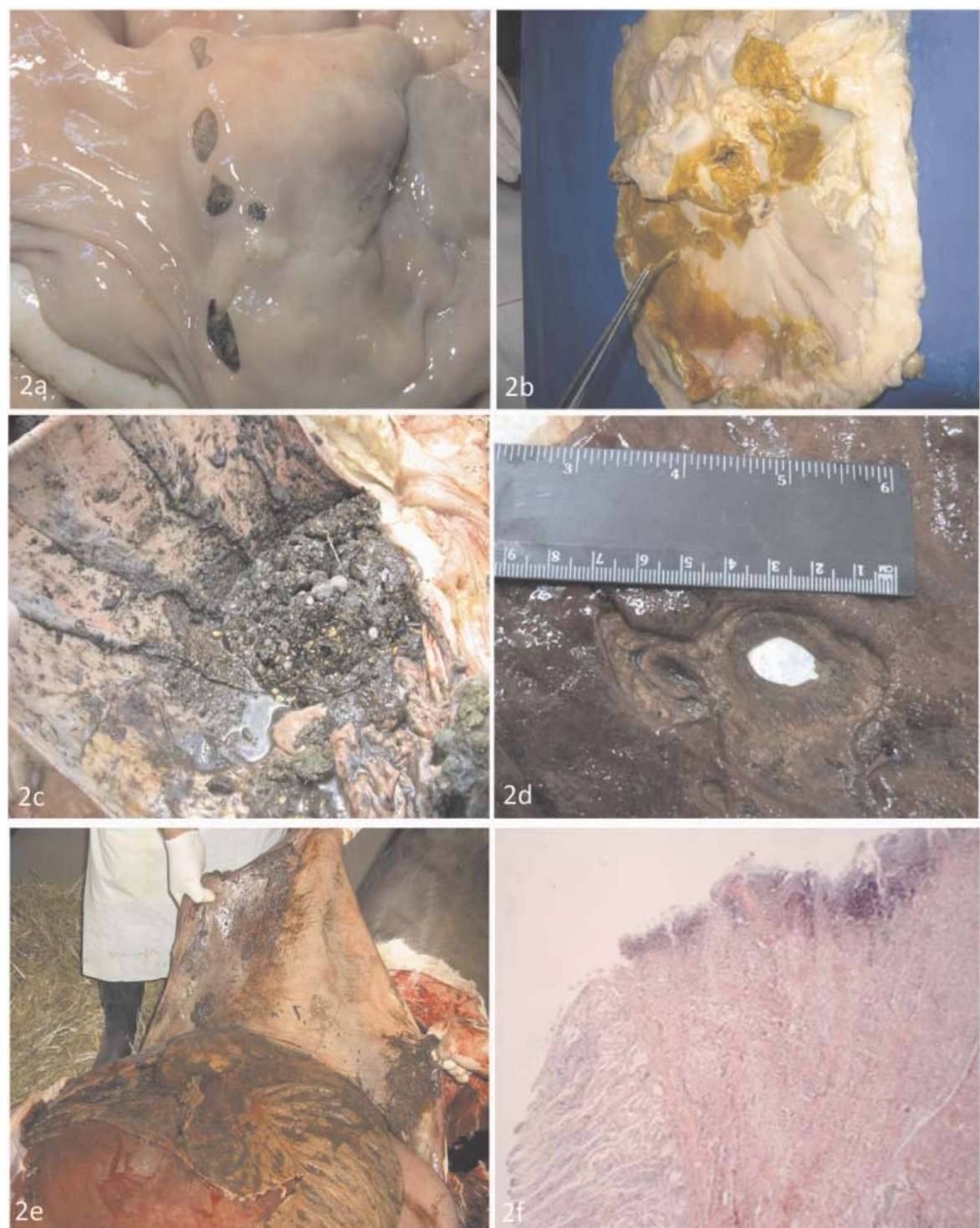

Figure 2. Cow abomasum; $2 \mathrm{a}$ - ulcerations type 1 and 2 in a cow suffering from lymphoma; $2 \mathrm{~b}$ - perforatingulcer type 3 with circumscript adhesive peritonitis; $2 \mathrm{c}$ - eosediment; $2 \mathrm{~d}$ - concurrent ulcers type 1 and type $4 ; 2 \mathrm{e}$ - diffuse perritonitis in a cow suffering from type 4 uler, 21 - ulcer H\&E x 10

Mycotic ulcerative abomasitis was diagnosed in a cow which died seven days after calving. The ulcers were multiple, round, sometimes confluent and present in the corpus and pylorus of the abomasum. They were characterized with 
a necrotic centre with a deeply escavated defect and a hyperemic-haemmorhagic margin which was prominent to the ulcus and thus narrowing the opening (Figure 3a). Fungi Asperigillus fumigatus and Mucor spp. were isolated. Histopathological analysis of samples dyed with the Grocott method showed septed and not septed fungal hyphae in the blood vessels and surrounding tissue of the tunica mucosa and submucosa (Figure 3b). From literature data is known that vasoactive fungi (Zygomycetae), such are species Mucor, Absidia, and rarely Aspergillus can cause thrombosis of the blood vessels and subsequent ischemia with arising ulcerations (Brown et al., 2007). It is possible that this was the case of overgrowth of fungi as the result of rumen acidosis and/or silage contaminated with Aspergillus fumigatus and Mucor spp.
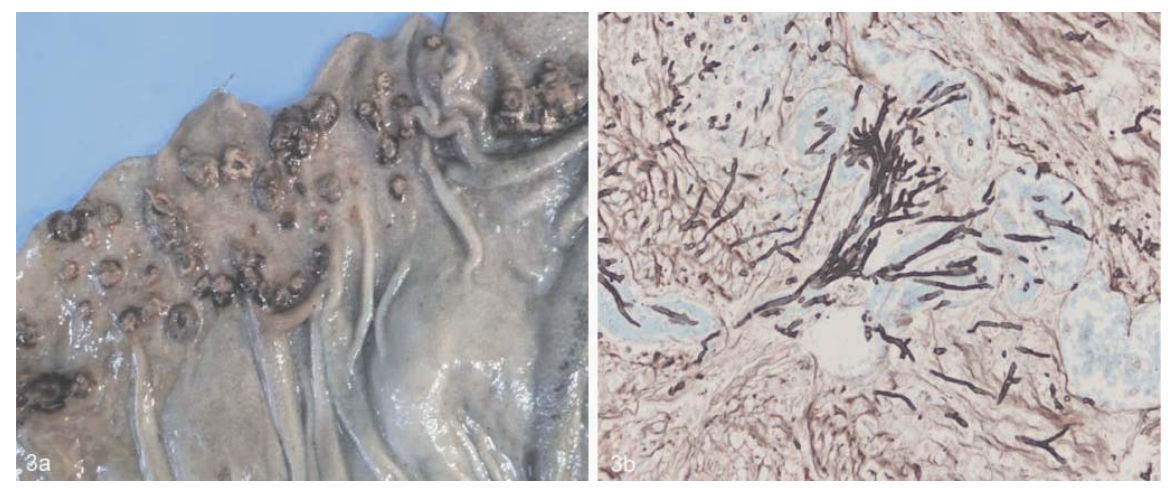

Figure 3. Cow abomasum: $3 a$ - mycotic ulcerative abomasitis; $3 b$ - septed and not septed fungus hyphae in the blood vessels and surounding submucosa tissue (Grocott $x$ 400)

Abomasal ulcers in the surveyed cattle occurred mainly in the corpus and pylorus, mostly were round or oval, and are represented by all four types. The cause of their occurrence may be related to stress (periparturient period, transportation), food, vasoactive fungi, the presence geosediments, and lymphoma of the abomasum. In these situations, secretion of gastric juice is stimulated by various mechanisms, compromised microcirculation or inhibited cytoprotectivity of the abomasal mucosa, which create conditions for the formation of ulcers.

ACKNOWLEDGMENT:

This work was supported by the Ministry of Education, Science and Technological Development, Projects No TR 31062 and III 46009

Address for correspondence:

Dr. Branislav Kureljušić

Department of Pathology

Institute of Veterinary Medicine of Serbia

Vojvode Toze 14

11000 Belgrade, Serbia

E-mail: branislavkureljusic@yahoo.com 


\section{REFERENCES}

1. Braun U, Eicher R, Ehrensperger F, 1991, Type 1 abomasal ulcers in dairy cattle, Zentralbl Veterinarmed $A, 38,357-66$.

2. Brown CC, Baker DC, Barker IK, 2007, The alimentary system. In: Jubb K. F., Kennedy P. C. and Palmer N. editors. Pathology of domestic animals. Vol $5^{\text {th }}$ ed. Academic Press, San Diego. USA. 1-297.

3. Burijan J, 1980, Poremećaji želuca. In: Stefanović S. Banićević B. Banković S. Burijan J. Glišić Lj. Đurić D. et al. Specijalna klinička fiziologija, Medicinska knjiga, III preštampano izdanje. Beograd-Zagreb.

4. Cable CS, Rebhun WC, Fubini SL, Erb HN, Ducharme NG, 1998, Concurrent abomasal displecment and perforating ulceration in cattle: 21 cases (1985-1996), J Am Vet Med Assoc, 212, 1442-5.

5. De Groote D, van Doorn LJ, Ducatelle R, Verschuuren A, Tilmant K, Quint WG et al., 1999, Phylogenetic characterization of 'Candidatus Helicobacter bovis', a new gastric helicobacter in cattle, Int J Syst Bacteriol, 49, 1707-15.

6. Dirksen G, 1989, Zur Klinik der Labmagengeschwure bei Kalb, Dug-Tagung Fachgrupe "Rinderkrankheiten", Berlin.

7. Johannsen U, Arnold P, Sachsenweger O, 1989, Untersuchungen zum Vorkommen von Labmagengeschwuren bei Rindern, Mh Vet-Med, 44. 1-5.

8. Lorch A, Rademacher G, 2004, Klinische Untersuchung des Rindes und Differenzialdiagnose praxisrelevanter Leitsymptome, Teil 6 Kuh mit beidseits vollem Abdomen infolge eines in die Bauchhöhle durchgebrochenen Labmagengeschwürs, Tierärztl Umschau, 59, 514-8.

9. Marshall TS, 2009, Abomasal ulceration and tympany of calves, Vet Clin Food Anim, 25, 209-20.

10. Ostertag R, 1989, Peptische Magengeschwüre beim Rind, Dtsch Z Tiermed, 14, 45-51.

11. Palmer JE, Whitlock RH, 1983, Bleeding abomasal ulcers in adult dairy cattle, J Am Vet Med Assoc, 183, 448-51.

12. Palmer JE, Whitlock RH, 1984, Perforated abomasal ulcers in adult dairy cows, J Am Vet Med Assoc, 184, 171-4.

13. Quinn PJ, Markey BK, Carter ME, Donnely WJC, Leonard FC, 2002, Veterinary Microbiology and Microbial Disease, Blackwell Science Ltd., lowa State University Press.

14. Rademacher G, Lorch A, 1999, Labmagenruptur beim Rind, Tierärztl Umschau, 54, 127-33.

15. Šamanc $A H, 2009$, Bolesti organa za varenje goveda, Univerzitet u Beogradu, Fakultet veterinarske medicine, Naučna KMD, Beograd.

16. Tehrani A, Javanbakht J, Marjanmehr AH, Hassan MA, Solati A, Dezfouli AB et al., 2012, A pathological lesions study of bovine abomasums in Urmia abattoir, $J$ Clin Exp Pathol, 2, 5.

17. Tharwat M, Ahmed AF, 2012, Abomasal ulceration in buffaloes and cattle: Clinico-biochemical and pathological findings, $J$ Anim Vet Adv, 11, 1327-31

18. Whitlock RH, 1980, Bovine Stomach Disease. In: Anderson NV. editor. Veterinary Gastroenterology, Philadelphia. Lea and Febiger, 425-8.

19. Zauscher T, 2007, Prospektive Untersuchungen zu pathologisch-anatomischen befunden bei Kühen mit perforierendem Labmagengeschwür, Inaugural Dissertation, Ludwig-MaximiliansUniversität, München. 


\section{ISPITIVANJE PATOMORFOLOŠKIH KARAKTERISTIKA ULKUSA ABOMAZUSA KOD VISOKO-MLEČNIH KRAVA}

KURELJUŠIĆ B, IVETIĆ V, SAVIĆ B, JEZDIMIROVIĆ N, CVETOJEVIĆ Đ, KURELJUŠIĆ JASNA, ILIĆ ŽIVKA, STANOJEVIĆ S i STEVANČEVIĆ M

\section{SADRŽAJ}

Ulkus abomazusa predstavlja lokalni proces autodigestije sluznice koja nastaje pod uticajem acidopeptičke aktivnosti ili je proizvod patofizioloških mehanizama pri kojima sluznica ne može da se suprotstavi destruktivnom dejstvu kiselog želudačnog soka, odnosno kada je narušena ravnoteža između protektivnih i agresivnih faktora. U poslednje vreme sve je više podataka u literaturi o pojavi ulkusa abomazusa progredijentnog toka kod visoko mlečnih krava. Cilj ovog rada je bio da se ispita morfologija, lokalizacija i tipizacija ulkusa abomazusa kod visokomlečnih krava, kao doprinos razjašnjenju ulcerogeneze.

U ovom radu je ispitano deset visoko-mlečnih krava koje su uginule u ranom puerperijumu i dve visokogravidne junice holštajn rase iz uvoza koje su uginule deset dana posle transporta, a poticale su sa farmi mlečnih goveda iz okoline Beograda. Nakon uginuća, izvršena je obdukcija i uzorci alterisanog tkiva abomazusa su uzorkovani za histopatološka i mikološka ispitivanja.

Ustanovljene ulceracije abomazusa kod deset obdukovanih životinja međusobno su se razlikovale kako po lokalizaciji i morfologiji tako i po stepenu zidne penetracije što ih diferencira u četiri tipa. Ulkusi tipa jedan i dva ustanovljeni su kod dve junice i šest krava, bili su multipli, situirani u korpusnoj i pilorusnoj regiji, jedan do drugog i većinom okruglog, ovalnog ili potpuno nepravilnog oblika i penetrirali su do submukoze ili dublje u mišićni sloj. Ulceracije tipa 1 i 2 ustanovljene su i kod jedne krave sa limfomom. Ulceracije su bile multiple i uglavnom ovalnog oblika, a smeštene u korpusu i pilorusu abomazusa u nizu. Perforirajući ulkus tipa tri sa cirkumskriptnim peritonitisom ustanovljen je kod jedne krave. Ulkus je prečnika $3 \mathrm{~mm}$ i nalazi se u korpusu abomazusa bliže kurvaturi major. Interesantan je nalaz simultane pojave perforirajućeg ulkusa tipa četiri i ulkusa tipa jedan koji su locirani jedan do drugog i dimenzija $7 \times 4 \mathrm{~cm}$.

Histopatološkim ispitivanjem uzoraka abomazusa sa ulceracijama bojenih hematoksilin-eozin metodom ustanovljena je koagulaciona nekroza u području ulceracije i umereni zapaljenski infiltrat u lamini propriji. Kod krave sa limfomom, je pored ovog ustanovljen i obilan tumorozni limfoidni proliferat.

Mikotični ulcerozni abomazitis ustanovljen je kod jedne krave sedam dana posle partusa. Ulceracije su multiple, okruglog oblika, ponekad konfluiraju, a zastupljene su na korpusnom i pilorusnom delu abomazusa. Iz ovih lezija izolovane su gljivice Aspergillus fumigatus i Mucor spp. Histopatološkom analizom, u uzorcima tkiva abomazusa obojenih Grocott metodom, dokazane su septirane i neseptirane hife gljivica u krvnim sudovima i okolnom tkivu tunike mukoze i submukoze.

Ulkusi abomazusa kod ispitanih krava se najčešće javljaju na korpusnoj i pilorusnoj regiji, većinom su okrugli ili ovalni, a zastupljeni su sa sva četiri tipa. Uzrok njihovog nastanka može se vezati za stresogene faktore (peripartalni period, transport), ishranu, vazoaktivne gljivice, prisustvo geosedimenta i limfom abomazusa. 